\title{
Zastosowanie metody vacuum casting do wytwarzania prototypów badawczych polimerowych kół zębatych
}

\author{
Rafał Oliwa ${ }^{1)}$, Mariusz Oleksy'), *), Maciej Heneczkowski ${ }^{1)}$, Grzegorz Budzik ${ }^{2)}$, Olimpia Markowska ${ }^{2)}$, \\ Łukasz Przeszłowski ${ }^{2)}$
}

DOI: dx.doi.org/10.14314/polimery.2017.036

\begin{abstract}
Streszczenie: Przeprowadzono badania dotyczące wykorzystania nanokompozytów na osnowie dwuskładnikowych żywic poliuretanowych typu RenPIM-VG 5286 (PUR) z dodatkiem nanonapełniaczy: Nanobent ${ }^{\circledR}$ ZR1 i ZR2, modyfikowanych oktakis(tetrametyloamonio)oktasilseskwioksanem i oktakis\{3-[N-(hydroksyetylo)dimetyloamino]propylo\}oktasilseskwioksanem $\mathrm{w}$ technologii vacuum casting (VC). Zbadano reaktywność kompozycji odlewniczych (czas żelowania i maksymalną temperaturę utwardzania) oraz właściwości tiksotropowe, które mają istotny wpływ na przebieg procesu technologicznego wytwarzania prototypów kół zębatych w matrycach silikonowych. Oznaczono także wpływ rodzaju nanonapełniacza na właściwości użytkowe uzyskanych kompozytów. Wykazano, że dzięki wprowadzeniu układu hybrydowych napełniaczy, uzyskano ograniczenie skurczu promieniowego i osiowego, co dało radykalną poprawę dokładności wymiarowej odlewanych kół zębatych.
\end{abstract}

Słowa kluczowe: dwuskładnikowa żywica poliuretanowa, czas żelowania, tiksotropia, nanonapełniacze, nanokompozyty, koła zębate, vacuum casting.

\section{Application of vacuum casting technology for manufacturing of polymeric gears prototypes}

Abstract: In this study, the nanocomposites based on two-component polyurethane resin RenPIM-VG 5286 (PUR) with added nanofillers Nanobent ${ }^{\circledR}$ ZR1 and ZR2, previously modified with octakis(tetramethylammonium)octasilsesquioxane and octakis\{3-[N-(hydroxyethyl)dimethylamino]propyl\}octasilsesquioxane, were examined for application to vacuum casting technology (VC). The reactivity of the molding compositions (gel time and maximum curing temperature) as well as their thixotropic properties, which have an important impact on the technology process of prototyping gears in silicone matrices, were investigated. The effect of nanofiller type on the functional properties of the resulting composites was also determined. It was demonstrated that by introducing the hybrid filler system, a reduction in radial and axial shrinkage was achieved, which led to a radical improvement in the dimensional stability of gear castings.

Keywords: two-component polyurethane resin, gel time, thixotropy, nanofillers, nanocomposites, gears, vacuum casting.

Szybkie prototypowanie (z ang. rapid prototyping - RP), ze względu na możliwość wytwarzania z dużą dokładnością wymiarową skomplikowanych geometrycznie przedmiotów bezpośrednio z modelu CAD, jest powszechnie stosowane do produkcji prototypów projektowych m.in. dla przemysłu lotniczego i samochodowego, wyrobów medycznych, produktów konsumpcyjnych itp. [1-4]. Zastosowanie technologii RP pozwala znacząco

\footnotetext{
1) Politechnika Rzeszowska, Wydział Chemiczny, Katedra Technologii i Materiałoznawstwa Chemicznego, ul. Powstańców Warszawy 6, 35-959 Rzeszów.

2) Politechnika Rzeszowska, Wydział Budowy Maszyn i Lotnictwa, Katedra Konstrukcji Maszyn, ul. Powstańców Warszawy 8, 35-959 Rzeszów.

*) Autor do korespondencji; e-mail: molek@prz.edu.pl
}

skrócić czas cyklu wytwarzania konstrukcji, a tym samym zmniejsza koszt produktu i zwiększa jej konkurencyjność [5, 6]. W związku z tym techniki szybkiego prototypowania tj.: stereolitografia (SLA), selektywne spiekanie laserowe (SLS), wytwarzanie modeli warstwowych (LOM), osadzanie stopionego materiału (FDM) oraz trójwymiarowe drukowanie (3DP) muszą spełniać rosnące wymagania wielu gałęzi przemysłu.

Stereolitografia, a także odlewanie próżniowe (z ang. vacuum casting - VC) są rutynowymi technikami wytwarzania skomplikowanych elementów dla celów szybkiego prototypowania. Stereolitografia jest jednym z najstarszych sposobów szybkiego wytwarzania prototypów. Zaletą tego sposobu jest możliwość tworzenia modeli o złożonej strukturze wewnętrznej i zewnętrznej, wymagających dużej dokładności i powtarzalności. Z kolei 
technika odlewania próżniowego jest najczęściej wykorzystywana do produkcji małych, prototypowych modeli trójwymiarowych. Głównymi zaletami tego procesu jest niski koszt oprzyrządowania i krótki czas wytwarzania w porównaniu do tradycyjnej produkcji form stalowych. Pierwszym krokiem metody odlewania próżniowego jest wykonanie formy silikonowej przy wykorzystaniu modelu otrzymanego zazwyczaj za pomocą SLA stanowiącego tzw. master model. Po utwardzeniu forma jest dzielona na dwie połowy, w celu usunięcia modelu RP. Uzyskane formy są przede wszystkim używane do odlewania szerokiej gamy materiałów poliuretanowych lub epoksydowych, co umożliwia wytwarzanie prototypów o określonych właściwościach [7].

Główną wadą prototypów, ograniczającą ich stosowanie w warunkach obciążenia, jest słaba wytrzymałość, mała dokładność wymiarowa oraz duży skurcz. W ciągu ostatnich kilku lat naukowcy podjęli się poprawy właściwości użytkowych i wytwarzania kompozytów wykorzystywanych w technologii szybkiego prototypowania. Kompozyty polimerowe, ze względu na łatwość ich formowania oraz znacznie lepszą sztywność i odporność na uderzenia, są szeroko stosowane $\mathrm{w}$ wielu gałęziach przemysłu i ich wykorzystanie stale rośnie [8-12]. Kompozyt hybrydowy o zoptymalizowanym składzie, dzięki połączeniu zalet komponentów, pozwala wyeliminować lub zminimalizować wady, które pojawiają się, gdy używane są polimery niemodyfikowane. Innym celem stosowania wzmocnień hybrydowych jest zmniejszenie anizotropii i poprawa jakości detalu, a także zminimalizowanie kosztów produktów - na przykład poprzez zastąpienie drogich napełniaczy, takich jak: włókna węglowe lub aramidowe bardziej ekonomicznymi (włókna szklane lub naturalne) - przy zachowaniu wymaganej wytrzymałości kompozytu. Wiele prac poświęconych jest określeniu wpływu dodatku napełniaczy do kompozytu na osnowie żywic poliuretanowych wzmocnionych matami szklanymi na właściwości mechaniczne próbek otrzymanych z wykorzystaniem technik stereolitografii i próżniowego odlewania [13-15]. Z kolei Sandoval i Wicker [16] wykazali, że dodanie wielościennych nanorurek węglowych (MWCNT) do żywicy epoksydowej stosowanej w SLA poprawiło wytrzymałość na rozciąganie oraz zginanie, odpowiednio, o 5,7 i $26 \%$, a także zmniejszenie modułu Younga o 10 \%, w stosunku do żywicy bez napełniacza.

Nasze wcześniejsze prace na temat hybrydowych kompozytów polimerowych oraz technologii szybkiego prototypowania $[17,18]$ wykazały, że kompozycje dwuskładnikowych żywic poliuretanowych przeznaczonych do szybkiego prototypowania z dodatkiem modyfikowanych glinokrzemianów oraz handlowych antypirenów charakteryzują się poprawioną wytrzymałością mechanicznac. Celem niniejszej pracy było zbadanie wpływu nowych modyfikowanych bentonitów i uniepalniaczy na reaktywność kompozycji poliuretanowych oraz właściwości mechaniczne nanokompozytów w zastosowaniach do produkcji prototypów kół zębatych.

\section{CZĘŚĆ DOŚWIADCZALNA}

\section{Materiały}

W badaniach wykorzystano następujące surowce: - dwuskładnikowa żywica poliuretanowa RenPIM-VG 5286 (PUR), produkcji firmy Huntsman (USA), składająca się ze składnika poliolowego i diizocyjanianu;

- Nanobent® ZR1 (NZR1) - bentonit modyfikowany IV-rz. solą amoniową (QAS), w której: $\mathrm{R}_{1}$ - podstawnik benzylowy, $R_{2} i R_{3}$ - podstawniki metylowe oraz $R_{4}$ podstawnik alifatyczny o liczbie atomów węgla C8 - C12 i Nanobent ${ }^{\circledR}$ ZR2 (NZR2) - bentonit modyfikowany QAS, w której: $R_{1}$ i $R_{4}$ - podstawniki alifatyczne o liczbie atomów węgla C10 - C12, $\mathrm{R}_{2} \mathrm{i} \mathrm{R}_{3}$ - podstawnikami metylowe. NZR1 i NZR2 wyprodukowano w ZGM Zębiec według technologii opracowanej w ramach grantu celowego nr 03933/C ZR7-6/2007;

- bentonit modyfikowany zgodnie z procedurą opisaną w patencie [19] oktakis(tetrametyloamonio)oktasilseskwioksanem (BP1);

- bentonit modyfikowany zgodnie z procedurą opisaną w patencie [19] oktakis\{3-[N-(hydroksyetylo)dimetyloamino]propylo\}oktasilseskwioksanem (BP2);

- krzemionka modyfikowana $20 \mathrm{cz}$. mas. mono[3-(2-aminoetyloamino)propylo]hepta(izobutylo)oktasilseskwioksanu (IHSP3), zgodnie z procedurą opisana w zgłoszeniu patentowym [20], dostarczona przez zespół prof. T. Jesionowskiego z Wydziału Technologii Chemicznej Politechniki Poznańskiej;

- wodorotlenek glinu $\mathrm{Al}(\mathrm{OH})_{3}$ o nazwie handlowej PYRAL 200 SM (AP) wyprodukowany przez firmę Nabaltec (Niemcy).

\section{Przygotowanie przedmieszek poliolowych z nanonapełniaczami}

Nanokompozyty PUR przygotowywano kilkuetapowo. Najpierw poliolowy składnik PUR wymieszano wstępnie z nanonapełniaczami za pomocą wolnoobrotowego mieszadła mechanicznego, a następnie w celu dokładnego zdyspergowania napełniacza w poliolu zastosowano trzystopniowy proces homogenizacji:

- mieszanie w szybkoobrotowym mikserze z mieszadłem turbinowym w temperaturze $50{ }^{\circ} \mathrm{C}$, przy szybkości obrotowej mieszadła $4000 \mathrm{obr} / \mathrm{min}$. Czas homogenizacji wynosił 30 min;

- homogenizację w ucieraku typu cylinder-cylinder o niewielkiej szczelinie 0,75 mm i szybkości obrotowej ruchomego cylindra równej 3000 obr/min, co zapewniało intensywne ścinanie. Czas trwania tej operacji wynosił $15 \mathrm{~min}$;

- mieszanie przez 15 min za pomocą homogenizatora ultradźwiękowego $\mathrm{w}$ temperaturze $50^{\circ} \mathrm{C}$.

Tak przygotowane kompozycje przechowywano w temperaturze ok. $4{ }^{\circ} \mathrm{C}$, by zapobiec możliwej sedymentacji napełniaczy i pogorszeniu właściwości przetwórczych mieszanek. 
T a b e l a 1. Skład badanych kompozycji na osnowie poliuretanowej (PUR) z dodatkiem BP1, BP2 i IHSP3

$\mathrm{T}$ a b 1 e 1. Compositions based on polyurethane resins (PUR) containing BP1, BP2 and IHSP3

\begin{tabular}{l|c|c|c}
\hline Symbol kompozytu & $\begin{array}{c}\text { Zawartość } \\
\text { BP1 } \\
\% \text { mas. }\end{array}$ & $\begin{array}{c}\text { Zawartość } \\
\text { BP2 } \\
\% \text { mas. }\end{array}$ & $\begin{array}{c}\text { Zawartość } \\
\text { hybrydowego } \\
\text { napełniacza } \\
\text { IHSP3 } \\
\% \text { mas. }\end{array}$ \\
\hline PUBP1-1,5 & 1,5 & - & - \\
PUBP1-3,0 & 3,0 & - & - \\
PUBP1-4,5 & 4,5 & - & - \\
PUIHSP3-1,5 & - & - & 1,5 \\
PUIHSP3-3,0 & - & - & 3,0 \\
PUIHSP3-4,5 & - & - & 4,5 \\
PUBP1IHSP3-1,5 & 0,75 & - & 0,75 \\
PUBP1IHSP3-3,0 & 1,5 & - & 1,5 \\
PUBP1IHSP3-4,5 & 2,25 & - & 2,25 \\
PUBP2-1,5 & - & 1,5 & - \\
PUBP2-3,0 & - & 3,0 & - \\
PUBP2-4,5 & - & 4,5 & - \\
PUBP2IHSP3-1,5 & - & 0,75 & 0,75 \\
PUBP2IHSP3-3,0 & - & 1,5 & 1,5 \\
PUBP2IHSP3-4,5 & - & 2,25 & 2,25 \\
\hline
\end{tabular}

Skład kompozycji PUR z badanymi dodatkami przedstawiono w tabelach 1 i 2.

Otrzymywanie kształtek do badań strukturalnych i wytrzymałościowych oraz prototypów kół zębatych z nanokompozytów PUR

Do 100 cz. mas. poliolu zawierającego odpowiednią ilość wytypowanych napełniaczy (tabela 1 i 2) dodano $150 \mathrm{cz}$. mas. diizocyjanianu (zgodnie z zaleceniami producenta żywicy PUR) i wymieszano. Następnie kompozycję odpowietrzono i odlewano w temperaturze pokojowej do form silikonowych przygotowanych zgodnie z normą ISO 527-1:1998 w laboratoryjnej komorze próżniowej VAKUUM UHG 400 (Firmy Schuechl, Niemcy). Kształtki następnie dotwardzano $\mathrm{w}$ temperaturze $80^{\circ} \mathrm{C}$ przez 2 godziny (zgodnie z zaleceniami producenta PUR).

\section{Metody badań}

\section{Pomiar pętli histerezy lepkości kompozycji}

Oznaczanie właściwości tiksotropowych badanych kompozycji wykonano $\mathrm{w}$ temperaturze $25^{\circ} \mathrm{C}$ za pomocą reometru rotacyjnego RheoStress RS6000. Zastosowano opisaną w literaturze metodę wyznaczania tzw. pętli histerezy płynięcia [21]. Mierzono lepkość przy wzrastających, a następnie malejących szybkościach ścinania. Do pomiarów użyto układu „płytka-stożek” o średnicy $20 \mathrm{~mm}$. Na postawie otrzymanych wyników obliczono pole powierzchni
T a b e 1 a 2. Skład badanych kompozycji na osnowie żywicy poliuretanowej (PUR) z dodatkiem ZR1, ZR2 i AP

$\mathrm{T}$ a b 1 e 2. Compositions based on polyurethane resin (PUR) containing ZR1, ZR2 and AP

\begin{tabular}{l|c|c|c}
\hline Symbol kompozytu & $\begin{array}{c}\text { Zawartość } \\
\text { NZR1 } \\
\% \text { mas. }\end{array}$ & $\begin{array}{c}\text { Zawartość } \\
\text { NZR2 } \\
\% \text { mas. }\end{array}$ & $\begin{array}{c}\text { Zawartość AP } \\
\% \text { mas. }\end{array}$ \\
\hline PUNZR1-1,5 & 1,5 & - & - \\
PUNZR1-3,0 & 3,0 & - & - \\
PUNZR1-4,5 & 4,5 & - & - \\
PUAP-1,5 & - & - & 1,5 \\
PUAP-3,0 & - & - & 3,0 \\
PUAP-4,5 & - & - & 4,5 \\
PUNZR1AP-1,5 & 0,75 & - & 0,75 \\
PUNZR1AP-3,0 & 1,5 & - & 1,5 \\
PUNZR1AP-4,5 & 2,25 & - & 2,25 \\
PUNZR2-1,5 & - & 1,5 & - \\
PUNZR2-3,0 & - & 3,0 & - \\
PUNZR2-4,5 & - & 4,5 & - \\
PUNZR2AP-1,5 & - & 0,75 & 0,75 \\
PUNZR2AP-3,0 & - & 1,5 & 1,5 \\
PUNZR2AP-4,5 & - & 2,25 & 2,25 \\
\hline
\end{tabular}

pętli histerezy płynięcia, które jest miarą energii niszczenia struktury tiksotropowej cieczy podczas ścinania.

\section{Oznaczanie reaktywności kompozycji}

Czas żelowania i maksimum temperatury utwardzania badanych przedmieszek poliolowych po dodaniu diizocyjanianu oznaczono $\mathrm{w}$ temperaturze $25{ }^{\circ} \mathrm{C}$ zgodnie z normą PN-EN ISO 2535:2004 za pomocą aparatu „Żelpenetrator WB-2". Na podstawie wyników pomiaru zmian temperatury $\mathrm{w}$ czasie utwardzania mieszaniny reakcyjnej uzyskano krzywą żelowania.

\section{Obserwacje mikrostruktury nanokompozytów}

Morfologię kruchych przełomów otrzymanych kompozytów analizowano z zastosowaniem skaningowego mikroskopu elektronowego typu SEM 234a (produkcji firmy JEOL Ltd., Japonia). Kruche przełomy uzyskano po ochłodzeniu kształtek w suchym lodzie i ich udarowym złamaniu.

\section{Badanie właściwości mechanicznych}

Wytrzymałość na rozciąganie określono zgodnie z normą PN-EN ISO 527-1:2012 przy użyciu maszyny wytrzymałościowej typu INSTRON 5967 zaopatrzonej w wideoekstensometr. Prędkość rozciągania wynosiła $2 \mathrm{~mm} / \mathrm{min}$, a temperatura pomiarów $23^{\circ} \mathrm{C}$.

Twardość wg Rockwella oznaczono za pomocą twardościomierza ZWICK 3106, zgodnie z normą EN 10109- 
-1:1994. Stosowano obciążenie wgłębnika równe 358 N. Jako wynik końcowy przyjęto średnią arytmetyczną z co najmniej 10 pomiarów.

Udarność wg Charpy'ego oznaczano zgodnie z normą PN-EN ISO 179-1:2010 za pomocą aparatu typu PSW4J, produkcji Gerhard Zorn (Niemcy) z wykorzystaniem młota o energii udarowej $1 \mathrm{~J}$ i cyfrowym odczytem wyniku.

\section{Badanie geometrii modeli kół zębatych}

Badanie wybranych odchyłek dokładności geometrycznej otrzymanych modeli kół zębatych przeprowadzono przy użyciu maszyny Wenzel LH87 wyposażonej w standardowe oprogramowanie Metrosoft CM3.7. Warunki badania były następujące: krok skanowania $0,5 \mathrm{~mm}$, prędkość skanowania $5 \mathrm{~mm} / \mathrm{s}$, średnica kulki pomiarowej $0,7 \mathrm{~mm}$.

\section{WYNIKI BADAŃ I ICH OMÓWIENIE}

\section{Analiza właściwości reologicznych przedmieszek}

Porównanie pola powierzchni pętli histerezy lepkości (pola zawartego między krzywą wyznaczoną przy wzrastających szybkościach ścinania a krzywą wyznaczona przy malejących szybkościach ścinania), które odpowiadają wartości pracy koniecznej do zniszczenia wiązań w strukturze tiksotropowej zestawiono w tabeli 3.

Stwierdzono, że kompozycje na osnowie PUR zawierające kombinacje napełniaczy BP1 lub BP2 z IHSP3 albo NZR1 lub NZR2 z AP charakteryzują się korzystnymi właściwościami tiksotropowymi (tabela 3). Zaobserwowano także wzrost pola powierzchni pętli histerezy lepkości wraz ze zwiększającą się zawartością użytych napełniaczy w kompozycji. Jednakże opisany efekt tiksotropii okazał się niewystarczający w trakcie odlewania prototypów kół zębatych. Zaobserwowano wyraźne zagęszczenie kompozycji zawierających 4,5\% mas. napełniaczy, co zdecydowanie utrudniało wypełnianie i odpowietrzanie gniazda formującego. W przypadku odlewania modeli kół z kompozycji zawierających 1,5 i 3,0 \% mas. dodatku napełniaczy nie zauważono podobnych zjawisk.

\section{Analiza reaktywności kompozycji}

Drugim bardzo istotnym parametrem w technologii VC jest reaktywność kompozycji polimerowej obejmująca czas żelowania i maksimum temperatury utwardzania. Znajomość tych dwóch wartości pozwala na poprawne prowadzenie procesu odlewania próżniowego. Z tego powodu oznaczono reaktywność badanych kompozycji po dodaniu diizocyjanianu. Wyniki oznaczenia czasów żelowania i maksimów temperatury utwardzania dla badanych kompozycji zestawiono w tabeli 3. Stwierdzono, że dodatek krzemionkowego układu hybrydowego IHSP3 do żywicy poliuretanowej nie wpływa na wydłużenie czasu żelowania. Natomiast obecność zmodyfiko-
T a b e 1 a 3. Wyniki oznaczeń pola powierzchni pętli histerezy oraz parametrów żelowania kompozycji na osnowie dwuskładnikowej żywicy poliuretanowej (PUR)

$\mathrm{T}$ a b l e 3. Rheological (hysteresis loop area) and gelation parameters for compositions of two-component polyurethane re$\sin$ (PUR)

\begin{tabular}{|c|c|c|c|}
\hline $\begin{array}{c}\text { Symbol } \\
\text { kompozytu }\end{array}$ & $\begin{array}{c}\text { Pole } \\
\text { powierzchni } \\
\text { pętli histerezy } \\
\text { lepkości, } \mathrm{J} / \mathrm{m}^{3}\end{array}$ & $\begin{array}{c}\text { Czas } \\
\text { żelowania } \\
\text { s }\end{array}$ & $\begin{array}{c}\text { Maksimum } \\
\text { temperatury } \\
\text { utwardzania } \\
{ }^{\circ} \mathrm{C}\end{array}$ \\
\hline PU & 0,0 & $132 \pm 4$ & $149,6 \pm 0,3$ \\
\hline PUBP1-1,5 & 4,4 & $172 \pm 2$ & $148,2 \pm 0,2$ \\
\hline PUBP1-3,0 & 8,9 & $187 \pm 2$ & $144,3 \pm 0,3$ \\
\hline PUBP1-4,5 & 10,8 & $194 \pm 3$ & $140,8 \pm 0,4$ \\
\hline PUIHSP3-1,5 & 4,3 & $132 \pm 4$ & $148,6 \pm 0,4$ \\
\hline PUIHSP3-3,0 & 9,1 & $140 \pm 2$ & $146,2 \pm 0,3$ \\
\hline PUIHSP3-4,5 & 10,6 & $153 \pm 4$ & $144,9 \pm 0,4$ \\
\hline PUBP1IHSP3-1,5 & 5,2 & $165 \pm 4$ & $148,8 \pm 0,2$ \\
\hline PUBP1IHSP3-3,0 & 11,6 & $177 \pm 2$ & $145,3 \pm 0,2$ \\
\hline PUBP1IHSP3-4,5 & 13,9 & $182 \pm 2$ & $142,8 \pm 0,2$ \\
\hline PUBP2-1,5 & 3,6 & $174 \pm 2$ & $147,6 \pm 0,4$ \\
\hline PUBP2-3,0 & 7,8 & $189 \pm 3$ & $144,1 \pm 0,3$ \\
\hline PUBP2-4,5 & 9,3 & $197 \pm 4$ & $140,3 \pm 0,4$ \\
\hline PUBP2IHSP3-1,5 & 4,3 & $172 \pm 4$ & $148,6 \pm 0,2$ \\
\hline PUBP2IHSP3-3,0 & 10,4 & $183 \pm 2$ & $144,9 \pm 0,3$ \\
\hline PUBP2IHSP3-4,5 & 11,9 & $199 \pm 4$ & $142,9 \pm 0,4$ \\
\hline PUNZR1-1,5 & 4,8 & $166 \pm 3$ & $148,8 \pm 0,3$ \\
\hline PUNZR1-3,0 & 9,6 & $175 \pm 2$ & $147,2 \pm 0,3$ \\
\hline PUNZR1-4,5 & 12,8 & $188 \pm 4$ & $145,8 \pm 0,2$ \\
\hline PUAP-1,5 & 2,1 & $147 \pm 2$ & $146,2 \pm 0,4$ \\
\hline PUAP-3,0 & 3,6 & $169 \pm 2$ & $145,3 \pm 0,3$ \\
\hline PUAP-4,5 & 4,2 & $187 \pm 2$ & $141,4 \pm 0,3$ \\
\hline PUNZR1AP-1,5 & 5,0 & $176 \pm 4$ & $148,8 \pm 0,2$ \\
\hline PUNZR1AP-3,0 & 10,9 & $187 \pm 3$ & $145,3 \pm 0,4$ \\
\hline PUNZR1AP-4,5 & 13,4 & $192 \pm 2$ & $142,8 \pm 0,2$ \\
\hline PUBP2-1,5 & 3,4 & $174 \pm 4$ & $142,3 \pm 0,2$ \\
\hline PUBP2-3,0 & 7,3 & $199 \pm 2$ & $140,2 \pm 0,2$ \\
\hline PUBP2-4,5 & 8,8 & $214 \pm 4$ & $137,7 \pm 0,3$ \\
\hline PUNZR2AP-1,5 & 4,0 & $178 \pm 2$ & $141,5 \pm 0,3$ \\
\hline PUNZR2AP-3,0 & 8,6 & $204 \pm 3$ & $139,6 \pm 0,5$ \\
\hline PUNZR2AP-4,5 & 9,1 & $220 \pm 2$ & $136,8 \pm 0,4$ \\
\hline
\end{tabular}

wanych bentonitów BP1, BP2, NZR1 i NZR2 powoduje, że wraz ze wzrostem ich stężenia w kompozycji następuje wydłużenie czasu żelowania (w zakresie od 7 do $67 \%$ ). Maksimum temperatury sieciowania ulega niewielkiemu obniżeniu. Dodatek modyfikowanej krzemionki do kompozycji zawierającej modyfikowany bentonit powoduje skrócenie (średnio o około 10 \%) czasu jej żelowania. Po wprowadzeniu AP do kompozycji nastąpiło wydłużenie (nawet o 42 \%) czasu żelowania, a jednocześnie nastąpiło obniżenie temperatury utwardzania, co może być spowodowane zmianami $\mathrm{pH}$ środowiska reakcji. 
a)

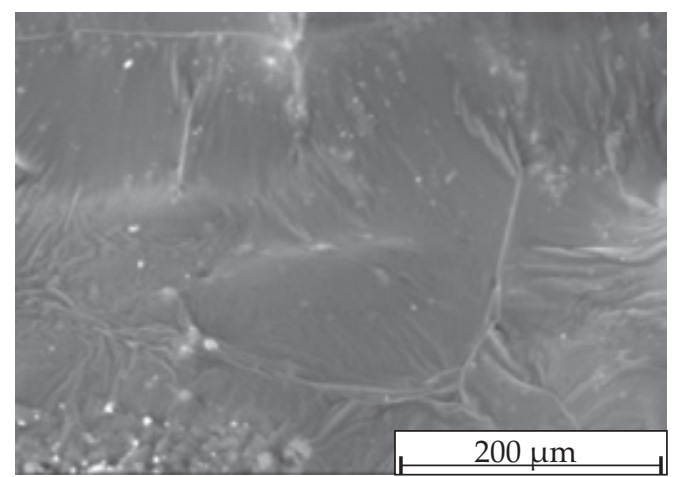

c)

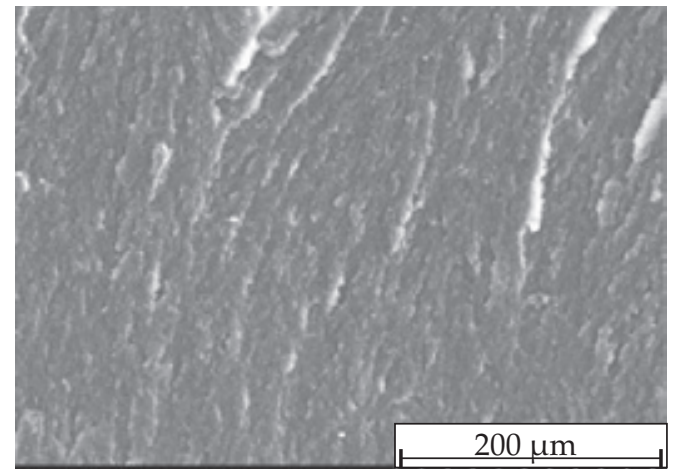

e)

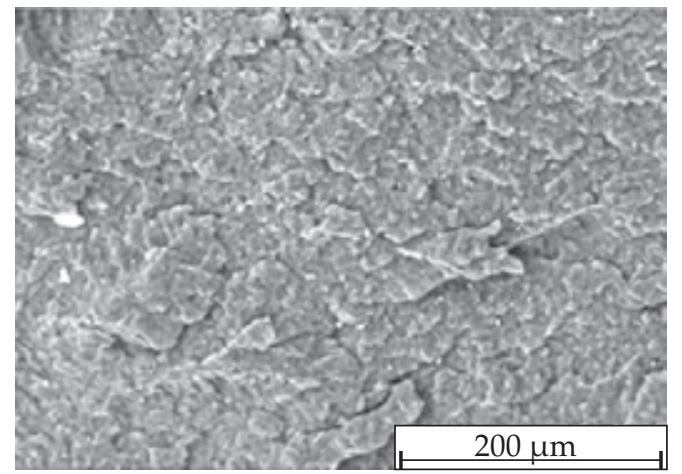

g)

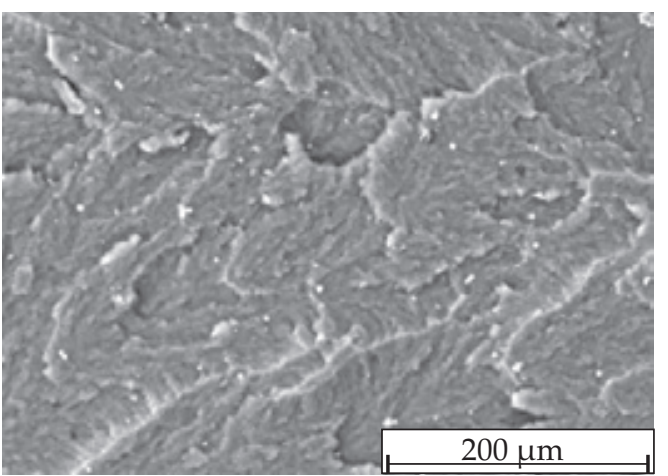

\section{Obserwacje mikrostruktury nanokompozytów}

Na podstawie mikrofotografii SEM kruchych przełomów badanych kształtek (rys. 1) stwierdzono, że w przełomie nienapełnionej utwardzonej żywicy PUR (rys. 1a) obserwujemy niewielkie bruzdy, prawdopodobnie przedstawiające obraz fazy twardej poliuretanu. Dodatek napełniaczy BP1 i BP2 do PUR sprawia, że przełomy próbek wyglądają jak poszarpane płytki z trudnymi do rozróżnienia fazami żywicy i napełniacza (rys. 1b i c). Taka morfologia wynika z warstwowej budowy modyfi- b)

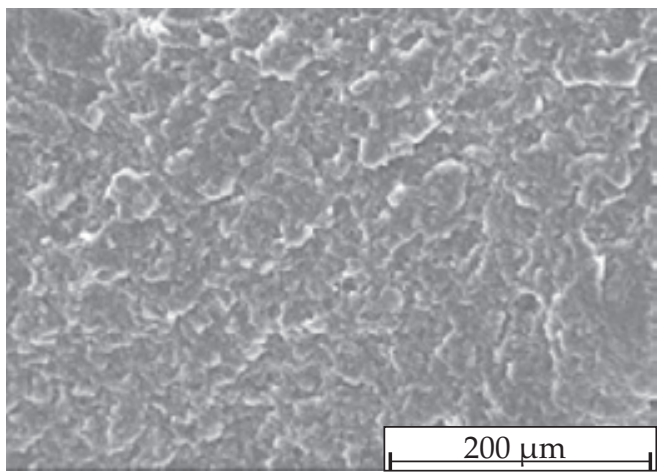

d)

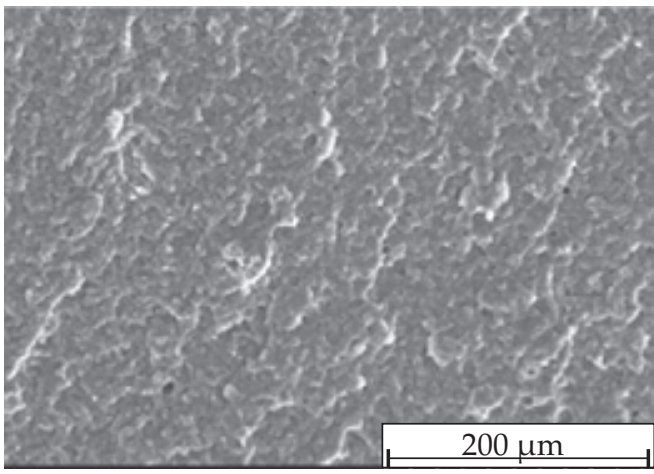

f)

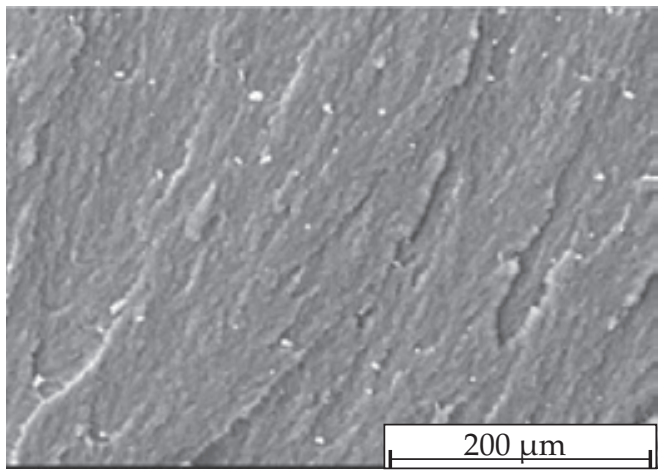

Rys. 1. Zdjęcia SEM kruchych przełomów próbek utwardzonego PUR (a) i kompozytów wytworzonych na jego osnowie: b) PUBP1-3,0, c) PUBP2-3,0, d) PUBP1IHSP3-3,0, e) PUNZR1-3,0, f) PUNZR2-3,0, g) PUNZR1AP-3,0

Fig. 1. SEM microphotographs of brittle fractures of cured PUR (a) and its composites: b) PUBP1-3,0, c) PUBP2-3,0, d) PUBP1IHSP3-3,0, e) PUNZR1-3,0, f) PUNZR2-3,0, g) PUNZR1AP-3,0

kowanych bentonitów oraz z ich organofilowego charakteru, który ułatwia dobrą mieszalność z badanymi żywicami. Drobnopłytkowa struktura kompozytu PUBP1-3,0 (rys. 1b) świadczy, że mamy do czynienia z nanokompozytem. W przypadku kompozytu PUBP2-3,0 (rys. 1c) obserwuje się aglomeraty napełniacza $\mathrm{w}$ matrycy żywicy, które pogarszają właściwości użytkowe kompozytów. Obecność w żywicy PUR układu hybrydowego napełniaczy IHSP3 powoduje powstanie struktury kompozytu o równomiernie rozproszonych niewielkich płytkach (rys. 1d). Natomiast dodatek nanobentów NZR1 i NZR2 
powoduje utworzenie struktury warstwowej (rys. 1e i f) charakterystycznej dla nanokompozytów. W przypadku hybrydowych nanokompozytów zawierających oprócz zmodyfikowanego bentonitu dodatkowo AP (rys. 1g) również nie zaobserwowano obecności aglomeratów.

\section{Właściwości mechaniczne hybrydowych nanokompozytów}

W celu określenia wpływu zastosowanych nanocząstek na właściwości mechaniczne badanych kompozytów jako materiałów do odlewania kół zębatych, wykonano oznaczenia: wytrzymałości na rozciąganie, modułu
Younga, twardości wg Rockwella i udarności wg Charpy'ego, a otrzymane rezultaty badań mechanicznych zestawiono w tabelach 4 i 5 .

Porównując dane przedstawione w tabelach 4 i 5 zaobserwowano wyraźny wpływ stosowanych nanonapełniaczy (BP1, BP2, IHSP3, NZR1 i NZR2) oraz ich stężenia na poprawę badanych właściwości wytrzymałościowych. Stwierdzono, że optymalna zawartość nanonapełniacza w kompozycie wynosi 3 \% mas. (tabela 4 i 5). Najlepsze rezultaty uzyskano dla kompozytów z dodatkiem NZR1, w przypadku których nastąpił wzrost: naprężenia zrywającego o ok. $23 \%$, modułu Younga o ok. $70 \%$, udarności o ok. $54 \%$ i twardości o ok. $16 \%$ (tabela 5). Najlepszą po-

T a b e 1 a 4. Oznaczenia właściwości mechanicznych nanokompozytów na osnowie dwuskładnikowej żywicy poliuretanowej (PUR) z dodatkiem BP1, BP2 i IHSP3

$\mathrm{T}$ a b 1 e 4. Mechanical properties of nanocomposites with two-component polyurethane matrix (PUR) containing BP1, BP2 and IHSP3

\begin{tabular}{l|c|c|c|c}
\hline \multicolumn{1}{c|}{ Symbol kompozytu } & $\begin{array}{c}\text { Naprężenie zrywające } \\
\mathrm{MPa}\end{array}$ & $\begin{array}{c}\text { Moduł Younga } \\
\text { GPa }\end{array}$ & $\begin{array}{c}\text { Udarność według } \\
\text { Charpy'ego, kJ/m }{ }^{2}\end{array}$ & $\begin{array}{c}\text { Twardość Rockwella } \\
\mathrm{MPa}\end{array}$ \\
\hline PU & $70,0 \pm 5,2$ & $2,0 \pm 0,31$ & $6,1 \pm 0,8$ & $41,3 \pm 2,8$ \\
PUBP1-1,5 & $74,0 \pm 2,1$ & $2,4 \pm 0,11$ & $7,2 \pm 0,7$ & $40,2 \pm 2,1$ \\
PUBP1-3,0 & $81,6 \pm 2,2$ & $3,1 \pm 0,23$ & $8,6 \pm 0,4$ & $40,9 \pm 2,0$ \\
PUBP1-4,5 & $83,2 \pm 2,7$ & $3,3 \pm 0,22$ & $9,1 \pm 0,5$ & $41,4 \pm 1,9$ \\
PUIHSP3-1,5 & $74,3 \pm 1,8$ & $2,5 \pm 0,16$ & $7,0 \pm 0,3$ & $43,2 \pm 1,1$ \\
PUIHSP3-3,0 & $81,5 \pm 1,6$ & $3,2 \pm 0,13$ & $8,3 \pm 0,5$ & $56,4 \pm 0,9$ \\
PUIHSP3-4,5 & $83,9 \pm 1,8$ & $3,5 \pm 0,20$ & $8,9 \pm 0,4$ & $66,2 \pm 1,4$ \\
PUBP1IHSP3-1,5 & $75,6 \pm 1,6$ & $2,7 \pm 0,19$ & $7,3 \pm 0,7$ & $43,2 \pm 1,1$ \\
PUBP1IHSP3-3,0 & $83,6 \pm 2,3$ & $3,4 \pm 0,23$ & $8,5 \pm 0,8$ & $56,4 \pm 0,9$ \\
PUBP1IHSP3-4,5 & $85,2 \pm 1,9$ & $3,6 \pm 0,22$ & $9,2 \pm 0,5$ & $66,2 \pm 1,4$ \\
PUBP2-1,5 & $72,3 \pm 1,1$ & $2,2 \pm 0,11$ & $6,7 \pm 0,5$ & $41,1 \pm 2,0$ \\
PUBP2-3,0 & $77,4 \pm 1,6$ & $2,4 \pm 0,13$ & $7,5 \pm 0,7$ & $42,2 \pm 2,3$ \\
PUBP2-4,5 & $79,3 \pm 1,7$ & $2,5 \pm 0,12$ & $8,6 \pm 0,4$ & $43,1 \pm 1,8$ \\
PUBP2IHSP3-1,5 & $73,9 \pm 1,4$ & $2,3 \pm 0,15$ & $7,1 \pm 0,5$ & $42,2 \pm 1,6$ \\
PUBP2IHSP3-3,0 & $79,3 \pm 1,3$ & $2,5 \pm 0,12$ & $8,4 \pm 0,6$ & $44,8 \pm 1,3$ \\
PUBP2IHSP3-4,5 & $80,2 \pm 1,6$ & $2,6 \pm 0,17$ & $8,2 \pm 0,2$ & $45,3 \pm 1,4$ \\
\hline
\end{tabular}

T a b e 1 a 5. Oznaczenia właściwości mechanicznych nanokompozytów na osnowie dwuskładnikowej żywicy poliuretanowej (PUR) z dodatkiem ZR1, ZR2 i AP

T a b l e 5. Mechanical properties of nanocomposites with two-component polyurethane matrix (PUR) containing ZR1, ZR2 and AP

\begin{tabular}{l|c|c|c|c}
\hline \multicolumn{1}{c|}{ Symbol kompozytu } & $\begin{array}{c}\text { Naprężenie zrywające } \\
\text { MPa }\end{array}$ & $\begin{array}{c}\text { Moduł Younga } \\
\text { GPa }\end{array}$ & $\begin{array}{c}\text { Udarność według } \\
\text { Charpy'ego, kJ/m }{ }^{2}\end{array}$ & $\begin{array}{c}\text { Twardość Rockwella } \\
\text { MPa }\end{array}$ \\
\hline PU & $70,0 \pm 5,2$ & $2,0 \pm 0,31$ & $6,1 \pm 0,8$ & $41,3 \pm 2,8$ \\
PUNZR1-1,5 & $76,9 \pm 1,4$ & $2,5 \pm 0,15$ & $7,4 \pm 0,3$ & $43,1 \pm 1,8$ \\
PUNZR1-3,0 & $84,3 \pm 1,6$ & $3,3 \pm 0,13$ & $8,9 \pm 0,5$ & $45,8 \pm 1,3$ \\
PUNZR1-4,5 & $85,9 \pm 1,3$ & $3,4 \pm 0,12$ & $9,4 \pm 0,3$ & $47,7 \pm 1,4$ \\
PUAP-1,5 & $71,4 \pm 1,2$ & $1,9 \pm 0,11$ & $6,4 \pm 0,4$ & $44,2 \pm 1,4$ \\
PUAP-3,0 & $75,6 \pm 1,4$ & $2,3 \pm 0,10$ & $7,2 \pm 0,2$ & $48,9 \pm 1,2$ \\
PUAP-4,5 & $77,1 \pm 1,7$ & $2,5 \pm 0,13$ & $7,9 \pm 0,4$ & $53,3 \pm 1,6$ \\
PUNZR1AP-1,5 & $74,7 \pm 1,6$ & $2,3 \pm 0,14$ & $6,8 \pm 0,3$ & $44,4 \pm 1,1$ \\
PUNZR1AP-3,0 & $78,9 \pm 1,3$ & $2,9 \pm 0,12$ & $7,8 \pm 0,4$ & $47,2 \pm 1,3$ \\
PUNZR1AP-4,5 & $82,3 \pm 1,4$ & $3,1 \pm 0,11$ & $8,3 \pm 0,2$ & $51,5 \pm 1,2$ \\
PUNZR2-1,5 & $74,8 \pm 1,2$ & $2,3 \pm 0,10$ & $7,2 \pm 0,3$ & $43,4 \pm 1,3$ \\
PUNZR2-3,0 & $80,1 \pm 1,3$ & $3,1 \pm 0,11$ & $8,1 \pm 0,2$ & $46,4 \pm 1,4$ \\
PUNZR2-4,5 & $82,3 \pm 1,2$ & $3,2 \pm 0,14$ & $8,9 \pm 0,3$ & $48,3 \pm 1,2$ \\
PUNZR2AP-1,5 & $73,3 \pm 1,3$ & $2,1 \pm 0,11$ & $6,7 \pm 0,3$ & $44,6 \pm 1,2$ \\
PUNZR2AP-3,0 & $75,4 \pm 1,1$ & $2,7 \pm 0,12$ & $8,4 \pm 0,2$ & $47,4 \pm 1,4$ \\
PUNZR2AP-4,5 & $79,2 \pm 1,2$ & $2,9 \pm 0,10$ & $51,8 \pm 1,3$ \\
\hline
\end{tabular}




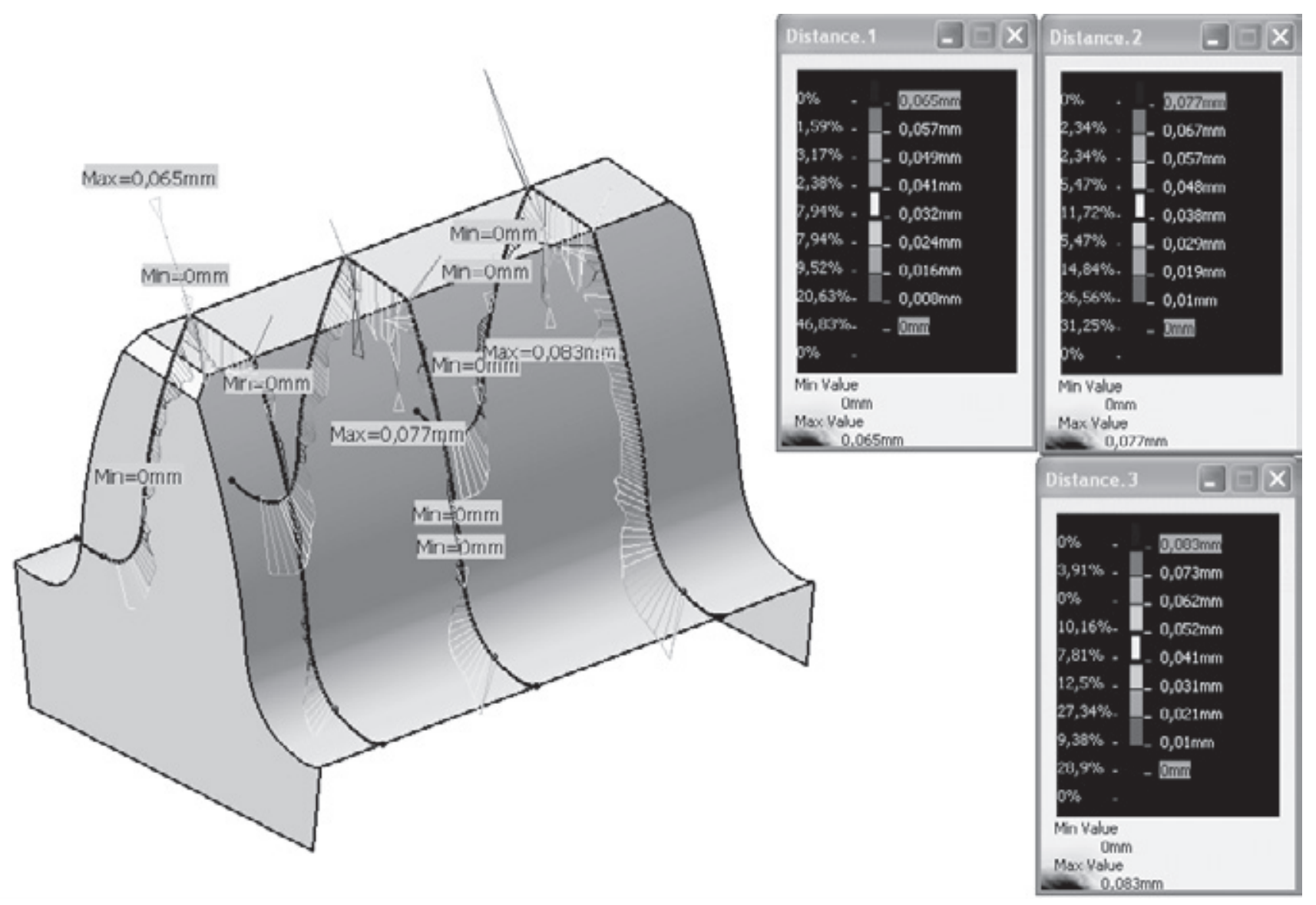

Rys. 2. Odchyłki zarysu zdefiniowane w przekroju czołowym

Fig. 2. Dimensional deviations in the frontal section

prawę właściwości użytkowych uzyskano dla hybrydowych nanokompozytów na osnowie PUR z dodatkiem nanonapełniaczy BP1 i IHSP3, gdzie zaobserwowano wzrost naprężenia zrywającego o ok. $22 \%$, modułu Younga o ok. $80 \%$, udarności o ok. 51 \% i twardości o ok. 60 \% (tabela 4).

Dane w tabeli 5 wskazują, że w przypadku kompozytów hybrydowych PUR z dodatkiem NZR1 i AP nastąpił wzrost naprężenia zrywającego o ok. $18 \%$, modułu Younga o ok. $5 \%$, udarności o ok. 36 \% i twardości o $25 \%$. Najmniejszą poprawę właściwości mechanicznych uzyskano dla kompozytów z dodatkiem AP, gdzie wystąpił tylko wyraźny, bo sięgający $25 \%$ wzrost twardości, a w przypadku naprężenia zrywającego i udarności poprawa omawianych cech była kilkuprocentowa. Natomiast w przypadku kompozytu zawierającego 1,5 \% mas. dodatku AP nastąpił $5 \%$ spadek modułu Younga i dopiero 3 lub 4,5\% mas. AP w kompozycie spowodowało wzrost modułu w zakresie 15-25\%.

\section{Ocena geometrii modeli kół zębatych}

Z analizy dokładności modeli przedstawionej na rys. 2 i w tabeli 6 wynika, że największe wartości odchyłek występują przy wierzchołku zęba (w każdym z przekrojów). Nie wpływają one jednak w istotny sposób na współpra- cę kół przekładni. W pozostałych punktach zarysu wielkości odchyłek są nieregularne.

Na podstawie analizy wymiarów (tabela 6) stwierdzono, że w przypadku kół zębatych otrzymanych z hybrydowego nanokompozytu zawierającego $3 \%$ mas.

T a b e 1 a 6. Średni zakres zmian w wymiarach kół zębatych otrzymanych $\mathrm{z}$ badanych kompozytów

$\mathrm{T}$ a b 1 e 6 . Average range of change in the dimension of gears made of polyurethane composites

\begin{tabular}{l|c}
\hline \multicolumn{1}{c|}{ Symbol kompozytu } & $\begin{array}{c}\text { Średni zakres zmian } \\
\text { w wymiarach koła, mm }\end{array}$ \\
\hline PU & od $-0,396$ do $+0,076$ \\
PUBP1-3,0 & od $-0,004$ do $+0,126$ \\
PUIHSP3-3,0 & od $+0,006$ do $+0,150$ \\
PUBP1IHSP3-3,0 & od $-0,002$ do $+0,125$ \\
PUBP2-3,0 & od $-0,022$ do $+0,131$ \\
PUBP2IHSP3-3,0 & od $-0,005$ do $+0,164$ \\
PUNZR1-3,0 & od $+0,001$ do $+0,161$ \\
PUAP-3,0 & od $-0,034$ do $+0,158$ \\
PUNZR1AP-3,0 & od $-0,005$ do $+0,177$ \\
PUNZR2-3,0 & od $-0,018$ do $+0,146$ \\
PUNZR2AP-3,0 & od $-0,035$ do $+0,156$ \\
\hline
\end{tabular}


mieszaniny napełniaczy nie zaobserwowano wpływu niekorzystnego zjawiska, jakim jest skurcz przetwórczy. Stwierdzono natomiast nieznaczne zwiększenie wymiarów kół w stosunku do modelu nominalnego, co może wynikać z większych rozmiarów gniazda formującego matrycy lub jej odkształcenia podczas odlewania, ze względu na elastomerowe właściwości żywicy silikonowej, która posłużyła do jej wykonania. Wpływ wymiarów gniazda formującego na dokładność geometryczną badanych kół zębatych będzie przedmiotem dalszych badań w przyszłości.

Na podstawie wyników analizy dokładności wykonania nanokompozytowych modeli odlewanych w matrycach silikonowych (tabela 6) można stwierdzić, że modele te mogą być $\mathrm{z}$ powodzeniem stosowane na etapie testów technologicznych nowych wyrobów.

\section{PODSUMOWANIE}

Obecność napełniaczy hybrydowych w kompozycie na osnowie żywicy PUR wyraźnie wpływa na zwiększenie właściwości tiksotropowych kompozycji. Optymalna ilość napełniaczy wprowadzona do żywic, pozwalająca na odpowiednie wypełnianie formy podczas odlewania niskociśnieniowego, mieści się w zakresie 1,5-3,0 \% mas.

Dzięki opracowaniu układu hybrydowych nanonapełniaczy oraz wielostopniowej homogenizacji uzyskano nanokompozyty hybrydowe o zdecydowanie poprawionych właściwościach mechanicznych w porównaniu do nienapełnionej żywicy (znaczący wzrost wartości udarności bez karbu i naprężenia zrywającego oraz wyraźne zwiększenie wartości modułu Younga).

W badanych kompozytach, dzięki wprowadzeniu układu hybrydowych napełniaczy, uzyskano ograniczenie skurczu promieniowego i osiowego, co spowodowało radykalną poprawę dokładności wymiarowej odlewanych kół zębatych. To z kolei zapewniło właściwe działanie przekładni zębatej. Najlepsze odwzorowanie wymiarów formy odlewniczej uzyskano dla modeli kół zębatych otrzymanych z kompozytu zawierającego 1,5\% mas. modyfikowanego bentonitu (BP1) i 1,5\% mas. modyfikowanej krzemionki (IHSP3).

\section{LITERATURA}

[1] Xu S., Li D., Lu B. i in.: Rapid Prototyping Journal 2007, $13,99$. http://dx.doi.org/10.1108/13552540710736786

[2] He J., Li D., Lu B. i in.: Rapid Prototyping Journal 2006, 12, 198. http://dx.doi.org/10.1108/13552540610682705

[3] Klosterman D., Chartoff R., Graves G. i in.: Composites, Part A: Applied Science and Manufacturing 1998, 29, 1165.

[4] Williams R.R., Howard W.E., Martin S.M.: Rapid Prototyping Journal 2011, 17, 92. http://dx.doi.org/10.1108/13552541111113835

[5] Chua C.K., Leong K.F.: "Rapid Prototyping: Principles and Applications in Manufacturing", John Wiley, Nowy Jork 1997.

[6] Wiedemann B., Jantzen H.A.: Computers in Industry 1999, 39, 11. http://dx.doi.org/10.1016/S0166-3615(98)00126-2

[7] Rosochowski A., Matuszak A.: Journal of Materials Processing Technology 2000, 106, 191. http://dx.doi.org/10.1016/S0924-0136(00)00613-0

[8] Osman M.A., Rupp J.E.P., Suter U.W.: Polymer 2005, 46, 8202. http://dx.doi.org/10.1016/j.polymer.2005.06.101

[9] Beyer G.: Fire and Materials 2002, 25, 193. http://dx.doi.org/10.1002/fam.776

[10] Ryszkowska J., Jurczyk-Kowalska M., Wiśniewski B.: Inżynieria Materiałowa 2006, 6, 1319.

[11] Pilawka R., Jesionowski T.: Kompozyty 2008, 4, 360.

[12] Swaminathan G., Shivakumar K.N., Sharpe M.: Composites Science and Technology 2006, 66, 1399. http://dx.doi.org/10.1016/j.compscitech.2005.09.008

[13] Karalekas D., Antoniou K.: Journal of Materials Processing Technology 2004, 153-154, 526. http://dx.doi.org/10.1016/j.jmatprotec.2004.04.019

[14] Zhong W., Lia F., Zhanga Z. i in.: Materials Science and Engineering: A 2001, 301, 125. http://dx.doi.org/10.1016/S0921-5093(00)01810-4

[15] Gupta A., Ogle A.A.: Polymer Composites 2002, 23, 1162. http://dx.doi.org/10.1002/pc.10509

[16] Sandoval J.H., Wicker R.B.: Rapid Prototyping Journal 2006, 12, 292. http://dx.doi.org/10.1108/13552540610707059

[17] Śliwa R., Oleksy M., Heneczkowski M.: Polimery 2015, 60, 667. http://dx.doi.org/10.14314/polimery.2015.667

[18] Oleksy M., Oliwa R., Zawiła B., Budzik G.: Polimery 2012, 57, 463. http://dx.doi.org/10.14314/polimery.2012.463

[19] Pat. PL 217487 (2013)

[20] Zgłosz. pat. PL 406559 (2013)

[21] Kembłowski Z., Petera J.: Rheologica Acta 1979, 18, 702. http://dx.doi.org/10.1007/BF01533344 